\title{
MEDIA LITERASI ALTERNATIF: STUDI KASUS PADA TEENLIT DI POSTINGAN INSTAGRAM AKUN "SASTRAARABCOM"
}

Hendro Eko Setiawan

Email: ekosetiawanh@gmail.com

Fakultas Adab dan Ilmu Budaya Universitas Islam Negeri Sunan Kalijaga, Yogyakarta

\begin{abstract}
The purpose of this research is to find teenlit in the Instagram account of Sastraarabcom which can be used as a medium to improve literacy culture among adolescents. to improve the literature faced by adolescents, writers must use various approaches, such as writing things they like, discussions, simulations, questions and answers and the like. Such a contextual approach is a key element in increasing adolescent learning interest. The results showed that teenlit Sastraarabcom can improve and become an alternative media in increasing teenage literacy, not only being able to read but can understand the contents of reading, with the hope of moral messages such as peace, social care, social values, mutual cooperation, values moral, and mutual respect between friends will be reflected in the actions of future adolescent behavior.
\end{abstract}

Keywords: Teenlit, new style of literacy, Instagram, sastraarabcom. 


\section{PENGANTAR}

Teenlit adalah gabungan kata dari kata teenager dan literature, Kata teenager adalah gabungan dari kata teens, age, dan sufiks-er. Teens artinya remaja dari 13 sampai 19 tahun, age berarti umur, dan sufiks-er dapat disamakan dengan prefiks pedalam bahasa Indonesia (Anggraini, 2014, hlm. 10). Menurut F.J. Monks, A.M.P. Knoers, Siti Rahayu Haditono, usia remaja dibagi dalam beberapa masa: pertama, masa peralihan dari kanak-kanak ke masa pubertas yaitu usia 12-14 tahun. Kedua, masa pubertas yaitu usia 14-16 tahun. Ketiga, masa peralihan pubertas ke remaja Adolesen yaitu usia 17-19 tahun. Terahir, masa remaja Adolesan yaitu usia 19-21 tahun (Mönks dkk., 1984, hlm. 262-263). Berdasarkan hal tersebut, teenlit dapat artikan sebagai bacaan untuk para remaja yang antara 13 tahun sampai 21 tahun. menurut istilah teenlit yaitu karya fiksi yang isinya menggambarkan kehidupan sosial para remaja. Teenlit mengangkat permasalahan yang tidak rumit dan penyajiannya sederhana (Mahmud, 1987, hlm. 2). Sastra remaja merupakan salah satu sastra populer yang banyak peminatnya dan kedudukannya patut diperhitungkan, dengan ciri karakter isi yang tidak rumit dan cenderung santai. Sastra populer mulai dianggap sebagai bidang studi yang sungguh-sungguh (Dewojati \& Sugihastuti, 2010, hlm. 10). Seejak itu, studi sastra remaja modern ini mulai berkembang, baik yang menghasilkan kritik akademik ataupun kritik nonakademik. Hal ini yang menyebabkan munculnya genre baru, salah satunya adalah teenlit.

Keberadaan teenlit dapat dipandang sebagai perkembangan sastra populer meskipun kedudukannya dalam sastra populer masih diperdebatkan. dalam beberapa tahun terakhir, penerbitan teenlit semakin banyak dalam industry buku di Indonesia. teenlit sangat populer di kalangan remaja, oleh karena itu penulis memandang bahwa teenlit perlu dipertimbangkan sebagai alternatif bahan pembelajaran apresiasi sastra di kalangan remaja. Gaya penulisan dalam teenlit sangat khas remaja. Bahasanya ringan dan mudah dimengerti, kebanyakan menggunakan bahasa lisan yang ditulis. alurnya sederhana, ceritanya sangat berkaitan dengan kehidupan seharihari khas anak muda. kemudahan dalam mengapresiasi teenlit tersebut tidak lantas membuat teenlit rendah nilainya.

Tidak semua teenlit bagus dan sesuai, namun ada beberapa judul teenlit yang memang layak dibaca di kalangan remaja. Penentuan kelayakan tersebut didasarkan pada aspek-aspek tertentu, yaitu aspek bahasa, aspek sosial budaya, dan aspek psikologi siswa. Ketiga aspek tersebut dalam praktiknya tidak dapat berdiri sendiri. Baik aspek bahasa, aspek latar belakang budaya, maupun aspek psikologi siswa, mempunyai kaitan satu dengan yang lain. Pertimbangan bahasa meliputi pemahaman siswa mengenai kosakata, variasi kalimat, dan gaya bahasa pengarang, termasuk di dalamnya adalah gaya tutur prokem dan bahasa slang khas anak muda (yang lazim disebut sebagai bahasa gaul).

Teenlit, seperti halnya novel yang bukan kategori novel remaja, memiliki unsur intrinsik yang akan menentukan kualitas kesastraan dari novel tersebut. Menurut Priyatni, unsur intrinsik prosa fiksi meliputi tema, amanat, tokoh dan penokohan, alur atau plot, latar, gaya bahasa, serta sudut pandang (Tri Priyatni, 2010, hlm. 110). Ketujuh unsur inilah yang mempunyai peran penting dalam 
penciptaan prosa fiksi. Pendapat ini sejalan dengan pendapat Wellek dan Warren menyatakan bahwa ketujuh unsur tersebut merupakan unsur yang membangun prosa fiksi (Wellek dkk., 2014). Selain itu, ada pendapat yang menyatakan bahwa amanat juga termasuk dalam unsur intrinsik karena amanat erat kaitannya dengan tema (Suroto, 1989, hlm. 89). Selain unsur instrinsik, prosa fiksi juga memiliki unsur ekstrinsik, yakni unsur yang berada di luar tubuh karya sastra (Suroto, 1989, hlm. 138).

Salah satu keluhan pengajar terhadap pembelajaran sastra di sekolah hingga saat ini adalah yaitu rendahnya minat membaca peserta didik. Kenyataannya, teenlit telah mampu membuktikan pengaruh positifnya bagi para remaja Indonesia, khususnya pada minat untuk membaca karya sastra. Hal ini dapat dilihat pada hasil sebuah survei yang dimuat dalam harian Republika bahwa teenlit telah mampu meningkatkan minat membaca para remaja khususnya remaja putri (Kusmarwanti, 2005).

Fenomena teenlit yang berkembang ini tidak bisa dilepaskan dari keberadaan remaja, baik keberadaan dunia remaja sebagai setting cerita, keberadaan remaja sebagai pembaca atau konsumen, maupun keberadaan remaja sebagai penulisnya. Oleh karena itu, untuk mengkaji perkembangan teenlit ini, diperlukan kajian terhadap kehidupan dunia remaja. Salah satu teenlit yang ada dalam media jejaring sosial ada pada akun instagram "Sastraarabcom" yang banyak diminati oleh nitizen khususnya para remaja di Indonesia, terbukti sejauh ini akun tersebut memiliki follower 47.900, dan 80 persen akun tersebut diikuti oleh para remaja (Admin, 2016, pada bagian usia pada akun instagram Sastraarabcom). Dalam akun tersebut banyak mengunggah teenlit yang berisi tentang kata-kata cinta, motivasi, politik, perjuangan dan tidak sedikit juga tentang nasihat.

Sastraarabcom menarik karena beberapa hal: kata-kata yang di unggah sangat eksplisit, bahasanya menarik karena terkadang ada yang diselingi dengan komedi, ceritanya relevan dengan kehidupan remaja zaman sekarang, serta bahasa yang digunakan jelas, di samping bahasa anak muda yang mudah dipahami pembaca.

Teenlit salah satu hasil kreativitas manusia yang memberikan alternatif kepada pembaca untuk menyikapi hidup karena tokoh dalam teenlit pada umumnya mencerminkan persoalan kehidupan manusia (Sumardjo \& Saini, 1995, hlm. 8). Diantara manfaat teenlit adalah dapat memberikan kebenaran hidup; mampu memberikan kepuasan dan kegembiraan batin; dapat memenuhi naluri manusia yang butuh keindahan; dan memberikan penghayatan yang mendalam terhadap apa yang diketahui dan menolong pembaca menjadi manusia yang berbudaya. Oleh sebab itu, penulis tertarik untuk menganalisis teenlit yang ada pada akun Sastraarabcom ini lebih mendalam.

Permasalahan dalam penelitian ini adalah: apakah teenlit pada postingan sastraarabcom dapat digunakan sebagai media untuk meningkatkan budaya literasi di kalangan remaja? Penelitian ini bertujuan untuk menemukan teenlit yang ada di dalam postingan Sastraarabcom serta seberapa jauh teenlit pada postingan sastraarabcom dapat digunakan sebagai media untuk meningkatkan budaya literasi di kalangan remaja. Penelitian ini diharapkan mampu menumbuhkan sikap positif remaja dalam mengapresiasi karya sastra. Jika sikap apresiasi tumbuh, dapat dikatakan bahwa tujuan pembelajaran sastra tercapai. 


\section{METODE PENELITIAN}

Secara etimologi, teenlit adalah akronim dari dua kata dalam bahasa Inggris, yaitu teenager dan literature. Mengacu pada pengertian tersebut, teenlit dapat diartikan sebagai bacaan yang bersegmentasi remaja (belasan tahun) yang mengangkat kehidupan remaja. Sebetulnya, teenlit bukanlah fenomena baru dalam sastra, di Indonesia mencatat adanya sebuah periodisasi bacaan sejenis teenlit pada tahun 1960-an yang disebut 'roman picisan.' Di tahun 1980-an berkembang pula novel serupa, Novel teenlit menjadi populer karena isinya tidak dibebani misi yang bermacam-macam. Dalam fiksi jenis ini tidak dijumpai struktur cerita yang kompleks, perenungan mendalam, ataupun gagasan tertentu yang hendak disampaikan. Pada tahun 2000 muncullah istilah teenlit (Syahrul, 2018, hlm. 11). Fenomena teenlit memberi dampak positif, setidaknya dalam dua hal. Pertama, keberhasilan para penulis dapat mendorong siapa saja untuk mulai mengikuti jejak mereka. Kedua, fakta bahwa beberapa teenlit berawal dari sebuah buku harian bisa menegaskan kembali bahwa menulis tidaklah serumit yang dibayangkan semula (Pramesthi, 2011, hlm. 17).

Membicarakan teenlit tentu tak bisa lepas dari chicklit. Perbedaannya, chicklit diarahkan pada pasar gadis dewasa 17-26 tahun, sedangkan teenlit untuk kaum wanita yang lebih belia, seusia murid SMP-SMA. Belakangan ini tidak sulit untuk mengenali keduanya, sebab selalu tertera tulisan "Teenlit" atau "Chicklit" pada setiap sampul depannya (Pramesthi, 2011, hlm. 12). Teenlit juga dipandang sebagai suatu fenomena dalam khazanah sastra populer. Bahasan mengenai sastra populer ini yang merupakan cikal-bakal teenlit telah dikemukakan oleh Jakob Sumardjo yang mengatakan bahwa: sastra modern yang kita kenal sekarang di Indonesia berasal dari kebudayaan Barat, dan sastra Barat yang berpengaruh di Indonesia adalah sastra Barat dalam perkembangan mutakhirnya pada abad ke-19. Dalam sastra Barat, pada waktu itu telah berkembang sastra populer di lingkungan kaum remaja yang meniru sastra kaum borjuis yang lebih terpelajar (Sumardjo \& Saini, 1995, hlm. 7-8).

Kualitas sastra populer sering dipertentangkan dengan sastra serius, termasuk bagaimana cara pengklasifikasiannya. Penggolongan seni sastra dalam genre tersebut tidaklah mudah, penggolongan sastra sejati dan sastra hiburan yang eskapisme bukanlah penggolongan seperti dalam ilmu eksakta, penggolongan itu lebih bersifat menunjukkan kecenderungan (Sumardjo \& Saini, 1995, hlm. 9). kata popular berasal dari bahasa Belanda yang mempunyai makna bentuk yang mudah dimengerti, sederhana dan disukai oleh orang banyak. Berangkat dari pengertian tersebut, maka sastra populer dapat diartikan sebagai sastra yang mudah dimengerti, sederhana, dan digemari banyak orang (Pramesthi, 2011, hlm. 13).

\section{Unsur-unsur Pembangun Teenlit}

Teenlit merupakan karya sastra jenis prosa yang merupakan perkembangan gaya penulisan. unsur-unsur pembangun teenlit pun sama dengan unsur-unsur pembangun novel, yaitu tema, alur, penokohan, gaya bahasa, amanat, latar (setting), sudut pandang (point of view). Penelitian ini bersifat deskriptif, dengan cara pengumpulan data menggunakan sumber data yaitu postingan yang ada di akun 
instagram Sastraarabcom. Informasi didapat dari hasil bacaan pada teenlit terkait yang selanjutnya sebagai data. Data yang diperoleh kemudian dianalisis dengan melakukan interpretasi, dideskripsikan dan kemudian dianalisis. Dalam usaha mencapai maksud yang telah ditentukan diperlukan teknik penelitian, yaitu teknik menganalisis data.

Langkah-langkah yang dilakukan untuk keperluan itu adalah sebagai berikut. Pertama, memilih dan membaca teenlit postingan yang ada di akun instagram Sastraarabcom dengan ancangan literasi kritis dan dipahami isinya kemudian dibuat sinopsisnya untuk mendapatkan data yang menyangkut menyuarakan ide tentang fakta sosial remaja. kemudian merumuskan simpulan penelitian tersebut yaitu membaca teenlit dengan ancangan literasi kritis teenlit dapat dijadikan media alternatif dalam meningkatkan literasi remaja dan mampu memahami isi bacaan akan tecermin dalam tindak dan perilaku kaum remanja pada masa yang akan datang.

\section{TINJAUAN PUSTAKA}

Penelitian ini dibuat berdasar pada tulisan-tulisan dari beberapa peneliti sebelumnya mengenai kemungkinan digunakannya teenlit sebagai bahan pembelajaran apresiasi sastra di sekolah, serta mengenai aspek-aspek penentu kelayakannya. Dalam tesis Kaswanto tahun 2007 yang berjudul Gaya Bahasa, Perwatakan, Tokoh dan Amanat Sebelas Cerpen dalam Kumpulan Cerpen Bidadari Meniti Pelangi' karya S. Prasetyo Utomo dan Implementasinya dalam Pengajarn Sastra di SMA, ia meletakkan aspek bahasa, aspek psikologi siswa, dan aspek latar belakang budaya siswa sebagai tiga aspek penting dalam pertimbangan pemilihan bahan pengajaran sastra.

Dari penelitian deskriptif-kualitatif tersebut diperoleh dua simpulan yaitu: (1) bahwa sebelas cerpen dalam kumpulan cerpen ini ditulis oleh pengarang menggunakan kosakata bahasa Indonesia baku yang sudah umum diketahui dan digunakan oleh siswa SMA; dengan penggunaan kosakata dan pola kalimat yang mudah dipahami oleh siswa SMA, mendorong siswa untuk menikmati dan mengapresiasi cerpen-cerpen tersebut, (2) berdasarkan pertimbangan aspek bahasa, psikologi siswa, dan aspek latar belakang budaya siswa, sebelas cerpen dalam kumpulan cerpen „Bidadari Meniti Pelangiee cocok diimplementasikan untuk pengajaran sastra pada siswa kelas XI semester 2. pada bagian saran Kaswanto menulis bahwa dengan hasil penelitian ini pula diharapkan dapat memberi alternatif bagi bahan pengajaran sastra di SMA. Jadi, penelitian tersebut memiliki beberapa kesamaan dengan penelitian yang penulis lakukan. Kesamaan tersebut terletak pada subjek penelitian, yaitu siswa SMA, dan pada pertimbangan pemilihan bahan pembelajaran sastra yaitu aspek bahasa, aspek psikologi siswa, dan aspek latar belakang budaya siswa. Dengan demikian, penelitian Kaswanto ini dapat menjadi pijakan bagi penulis. 


\section{ANALISIS DAN HASIL}

\section{Tema-Tema Teenlit Pada Postingan Instagram Sastraarabcom}

Salah satu teenlit yang menarik perhatian remaja adalah tema-tema yang ada di postingan instagram Sastraarabcom, Sastraarabcom memuat berbagai macam tema, diantaranya:

\section{Kata Mutiara}

Kata mutiara adalah unsur bahasa dari gabungan morfem yang diucapkan atau dituliskan sebagai perwujudan kesatuan perasaan dan pikiran dalam berbahasa yang memiliki makna yang sangat berharga. pengertian kata mutiara secara khusus berbeda dengan pengertian kata bijak meskipun memiliki fungsi dan tujuan yang relatif sama. seperti kita ketahui bahwa mutiara merupakan sebuah permata berbentuk bulat dan keras, terbentuk karena ada benda atau pasir yang masuk ke dalam tubuh kerang mutiara kemudian diselubungi oleh kulit ari, karena bentuknya yang sangat indah dan berkilau maka mutiara menjadi perhiasan yang berharga dan mahal. oleh karena itu, kata mutiara dapat dikatakan sebuah kata yang berharga karena memiliki makna yang indah seperti permata (Bijak, 2019). fungsi dan tujuan dari kata mutiara adalah sebagai kata-kata inspirasi maupun motivasi bagi seseorang yang mendengar atau membaca. Kata mutiara dianggap akan dapat bermanfaat bagi seseorang dalam menjalani kehidupan karena memiliki berbagai makna yang dapat meningkatkan kebajikan dan kebijaksanaan hidup, terkadang kata-kata bijak merupakan kata-kata mutiara juga yaitu sebuah kata-kata berupa nasihat, petuah atau saran positif yang berharga dan memiliki makna yang indah seperti mutiara, Kata- kata mutiara dalam artian yang sebenarnya adalah kata kata yang memiliki makna yang dalam. Kata-kata ini biasanya banyak muncul dari perenunganperenungan yang dalam tentang hidup, layaknya sebuah mutiara harus melalui proses panjang hingga kilaunya terbentuk.

Misalkan kata mutiara cinta yakni quote atau kutipan dari seseorang yang mengatakan sesuatu berkaitan dengan cinta, tema yang selalu ramai diperbincangkan, selalu hangat untuk dibahas, Memang tema ini sebenarnya adalah salah satu dari tema kehidupan, Begi penulis, cinta itu menarik bila dikaitkan dengan puisi, sajak atau kata kata mutiara, karena cinta itu bisa sangat abstrak sekaligus bisa begitu gamblang, bahkan perasaan kita sendiri ketika cinta itu jatuh bisa saja tidak menyadarinya, bila kita melihat seorang teman tiba-tiba sering berpuisi, mengatakan kata kata yang puitis, bisa jadi ia sedang jatuh cinta.

Pada postingan sastraarabcom banyak memuat kata mutiara, kususnya tentang cinta yang di kemas dalam bentuk puisi maupun prosa. Tema tersebut berhasil menarik perhatian pembaca khususnya para remaja, terbukti dari setiap postingan, tidak kurang dari 3000 like, teenlit pada postingan ini ada pada kata "tak, sesiapa, kau" dalam kalimat "cinta, bukan ketika kedua matamu tak memandang siapa selainku. Melainkan ketika aku selalu tampak diantara kau san siapa yang kau pandang". 
contoh postingan:

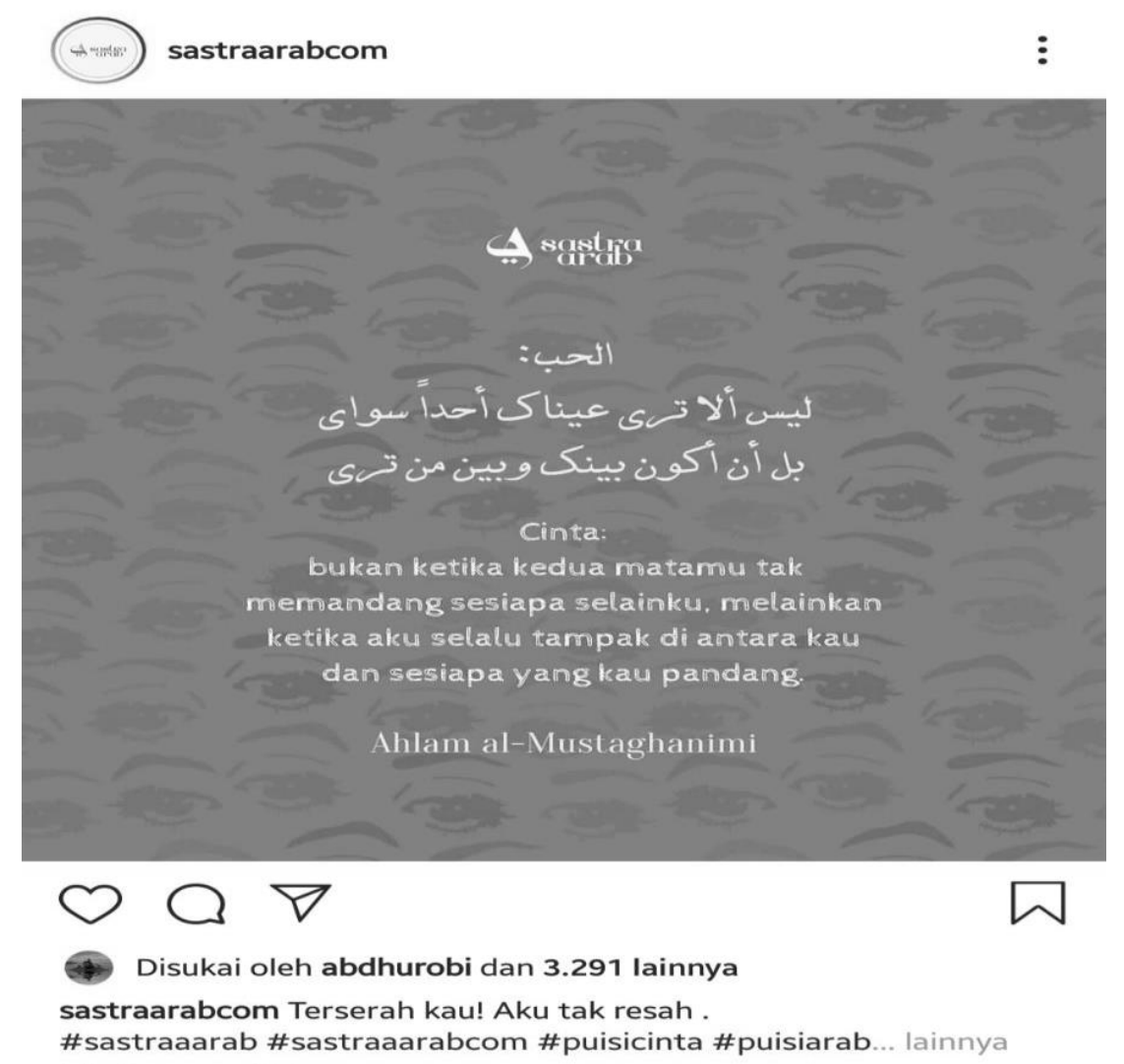

\section{Kata Bijak}

Kata Bijak terdiri dari dua penggabungan kata yang berbeda, yaitu kata dan bijak, menelisik pengertian kata adalah unsur bahasa yg diucapkan atau dituliskan yg merupakan perwujudan kesatuan perasaan dan pikiran yg dapat digunakan dalam berbahasa, sementara Bijak adalah selalu menggunakan akal budi. Dengan demikian, maka kata bijak dapat diartikan sebagai ucapan atau tulisan yang selalu menggunakan akal budi (Arman, 2011).

Kehidupan yang beranekaragam dan sangat keras, hal ini membutuhkan sesuatu yang membangun diri kita. Karena setiap manusia akan terpengaruh dengan adanya sebuah ungkapan yang disampaikan oleh setiap orang yang dia temui. tentunya dengan adanya kata kata bijak manusia tersebut akan mendapatkan sebuah pencerahan. Tidak hanya itu saja, adanya kata bijak juga memberikan sebuah motivasi tersendiri bagi seorang yang mendengarnya. hal ini karena sistem alam bawah sadar kita yang sudah terpengaruh oleh kata kata bijak tersebut, dalam kehidupan memang lika-liku masalah akan terus di alami oleh manusia namun dengan adanya sebuah motivasi dari kata yang diungkapkan maka tentunya masalah yang terjadi tersebut bisa cepat diselesaikan oleh manusia tersebut, dengan harapan nantinya masalah akan dapat segera terselesaikan dengan damai.

Bagi sebagian orang termasuk penulis, beranggapan bahwa semua kata bijak memang berisi tentang kebaikan dan kebenaran, namun tak semua kebijaksanaan itu bersumber dari segala sumber yaitu alquran dan hadis, tak semua kata bijak mengandung kaidah-kaidah keislaman, konsep-konsep yang tidak islami, meskipun 
sekilas terlihat benar. kata tersebut berfungsi sebagai trigger atau pemacu seseorang untuk lebih bersemangat ketika melakukan sesuatu, entah itu dalam bidang karir, pekerjaan, kehidupan, pendidikan, pernikahan, sekolah. olahraga ataupun hal-hal lainnya. memiliki kekuatan, kecerdasan dan penilaian untuk sebuah kebenaran. Biasanya kata-kata bijak berisi nasihat dan saran membangun atau bisa juga petuah untuk memotivasi dan mengambil keputusan secara tegas. Penggunaan kata-kata bijak tidak hanya ditujukan langsung kepada personal semata, tetapi pada situasi. Definisi kata bijak berbentuk sopan, baik, dan teratur. Sehingga, pendengar atau pembacanya tidak akan tersinggung, malah merasa jauh lebih nyaman. Kata bijak memiliki makna yang dalam, kata bijak menyerupai sebuah pesan atau nasehat untuk menggugah hati orang. Kata-kata tersebut juga bisa digunakan untuk memberikan antusiasme, spirit atau dorongan energi karena susunan katanya jelas dan mudah meresap secara langsung, dalam postingan sastraarabcom hampir didominasi oleh kata-kata bijak, baik mengutip dari sastrawan terkenal maupun kata-kata yang dirangkai sendiri. Kata-kata bijak yang ada di postingan instagram Sastraarabcom berhasil menarik perhatian pembaca. Dari setiap postingan yang bertemakan kata-kata bijak, tidak kurang dari 2.500 like, bahkan lebih.

Berikut ini contoh kata bijak yang ada dalam postingan sastraarabcom:

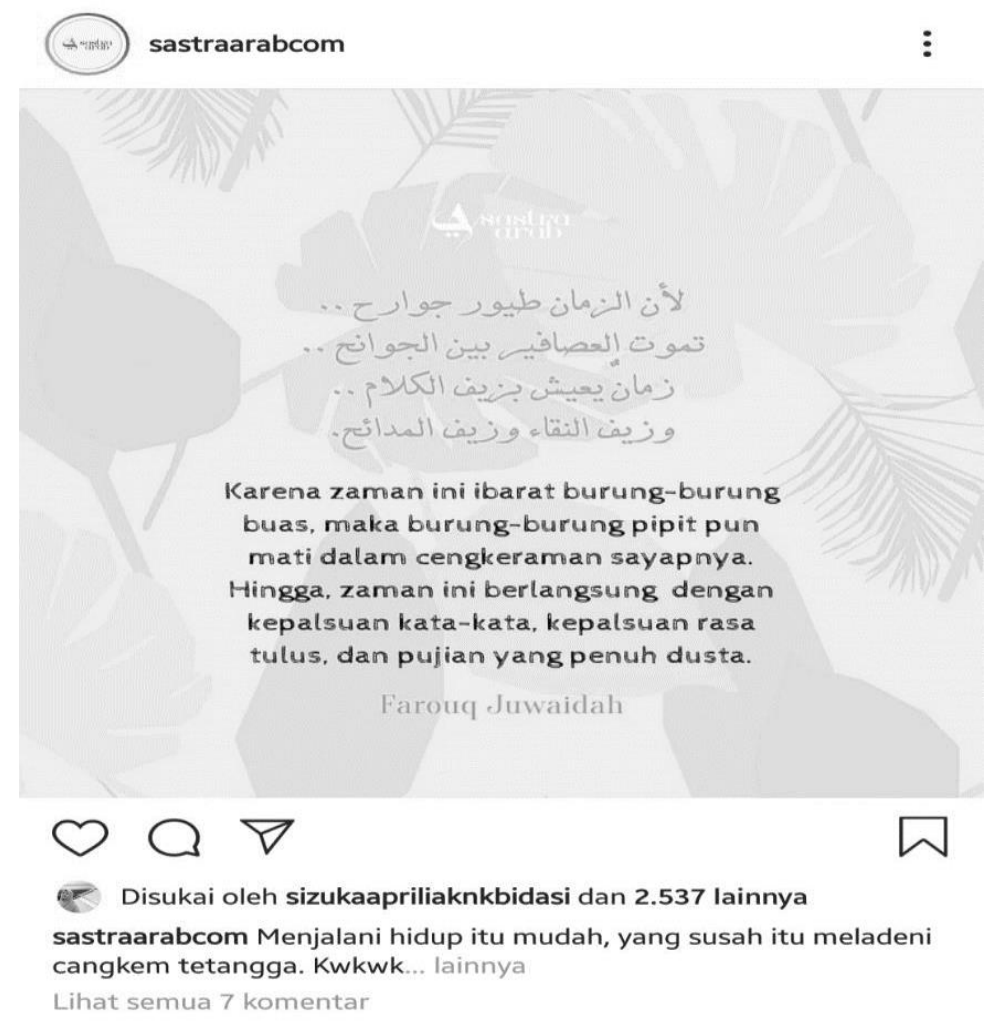

Teenlit pada contoh diatas terdapat pada kalimat "karena zaman ini ibarat burung-burung buas" (sebagai kalimat Konotasi), dan pada kalimat "maka burungburung pipit pun mati dalam cengkraman sayapnya"( sebagai kalimat Denotasi). 


\section{Motivasi}

Selanjutnya tema yang diusung dalam postingan instagram Sastraarabcom adalah tentang motivasi. Motivasi adalah sesuatu apa yang membuat seseorang bertindak. Efendi menyatakan bahwa motivasi merupakan dampak dari interaksi seseorang dengan situasi yang dihadapinya, motivasi menjadi suatu kekuatan, tenaga atau daya, atau suatu keadaan yang kompleks dan kesiapsediaan dalam diri individu untuk bergerak ke arah tujuan tertentu, baik disadari maupun tidak disadari (Efendi \& Nursalam, 2008, hlm. 14). Motivasi seseorang dapat ditimbulkan dan tumbuh berkembang melalui dirinya sendiri dan dari lingkungan, Motivasi intrinsik bermakna sebagai keinginan dari diri sendiri untuk bertindak tanpa adanya rangsangan dari luar, Motivasi intrinsik akan lebih menguntungkan dan memberikan keajegan dalam belajar. Motivasi ekstrinsik dijabarkan sebagai motivasi yang datang dari luar individu dan tidak dapat dikendalikan oleh individu tersebut. Elliott et al mencontohkannya dengan nilai, hadiah, dan/atau penghargaan yang digunakan untuk merangsang motivasi seseorang (Efendi \& Nursalam, 2008, hlm. 14). Misalnya, dalam kegiatan belajar, motivasi merupakan daya penggerak yang menjamin terjadinya kelangsungan kegiatan belajar dan memberikan arah pada kegiatan belajar sehingga tujuan yang diinginkan dapat terpenuhi. dengan demikian motivasi sangat berpengaruh terhadap hasil belajar seseorang. Apabila seseorang tidak mempunyai motivasi untuk belajar, maka orang tersebut tidak akan mencapai hasil belajar yang optimal. Untuk dapat belajar dengan baik di perlukan proses dan motivasi yang baik, memberikan motivasi kepada pembelajar, berarti menggerakkan seseorang agar ia mau atau ingin melakukan sesuatu.

Dari penjelasan diatas motivasi dapat diartikan sebuah alasan atau dorongan seseorang untuk bertindak. Orang yang tidak mau bertindak sering kali disebut tidak memiliki motivasi. Alasan atau dorongan itu bisa datang dari luar maupun dari dalam diri. Sebenarnya pada dasarnya semua motivasi itu datang dari dalam diri, faktor luar hanyalah pemicu munculnya motivasi tersebut. motivasi dari luar adalah motivasi yang pemicunya datang dari luar diri kita. sementara meotivasi dari dalam ialah motivasinya muncul dari inisiatif diri kita. Pada dasarnya motivasi itu hanya dua, yaitu untuk meraih kenikmatan atau menghindari dari rasa sakit atau kesulitan. uang bisa menjadi motivasi kenikmatan maupun motivasi menghindari rasa sakit. jika kita memikirkan uang supaya kita tidak hidup sengsara, maka disini alasan seseorang mencari uang untuk menghindari rasa sakit. Sebaliknya ada orangyang mengejar uang karena ingin menikmati hidup, maka uang sebagai alasan seseorang untuk meraih kenikmatan. Sastraarabcom berhasil menarik perhatian remaja dengan mengusung tema ini, terlihat dalam salah satu postingannya terdapat 3265 like dari nitizen. Berikut contoh kata motivasi yang di muat sastraarabcom: 


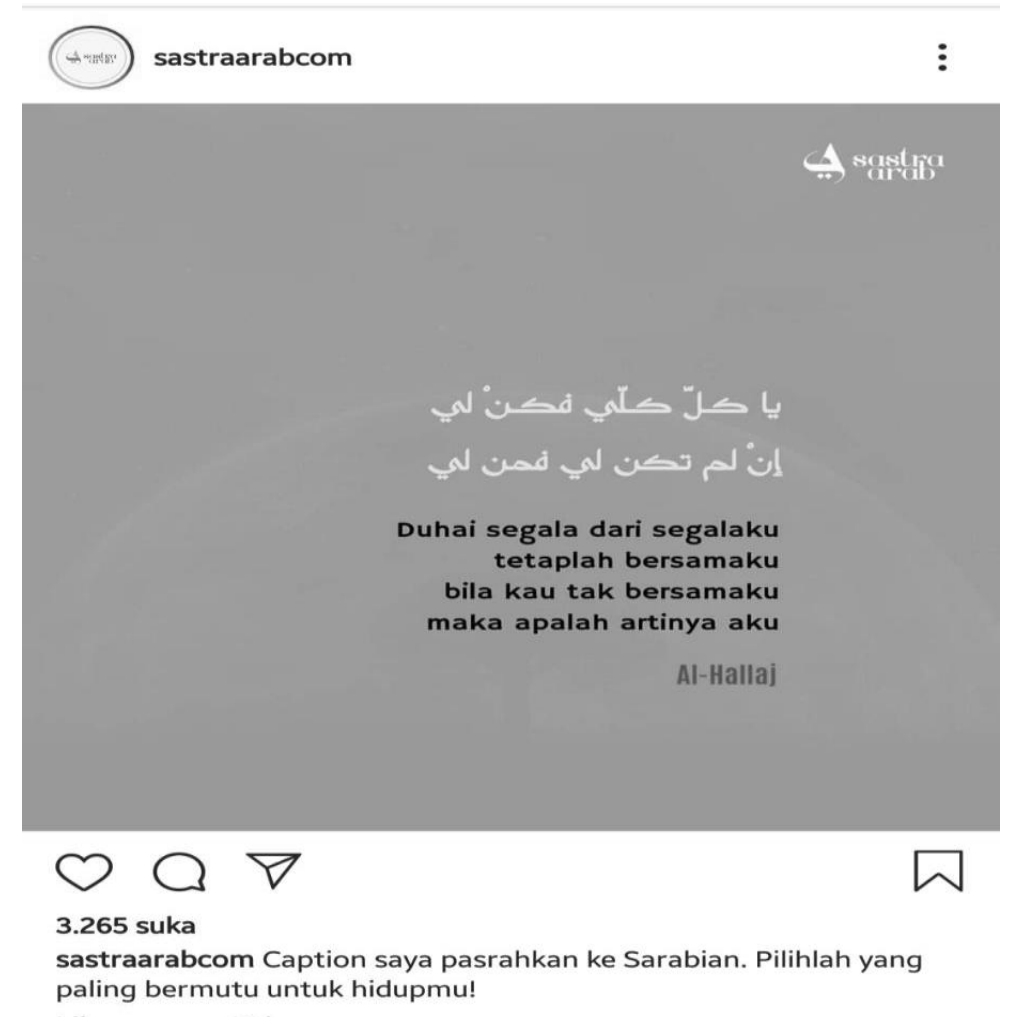

Teenlit pada postingan diatas terdapat pada kata "kau tak, apalah" dalam kalimat "bila kau tak bersamaku maka apalah artinya aku". Pada caption juga terdapat teenlit berupa kata "Sarabian".

\section{Politik}

Secara etimologis, politik berasal dari kata Yunani polis yang berarti kota atau negara kota. Kemudian arti itu berkembang menjadi polites yang berarti warganegara, politeia yang berarti semua yang berhubungan dengan negara, politika yang berarti pemerintahan negara dan politikos yang berarti kewarganegaraan. Aristoteles (384-322 SM) dapat dianggap sebagai orang pertama yang memperkenalkan kata politik melalui pengamatannya tentang manusia yang ia sebut zoon politikon. Dengan istilah itu ia ingin menjelaskan bahwa hakikat kehidupan sosial adalah politik dan interaksi antara dua orang atau lebih sudah pasti akan melibatkan hubungan politik. Aristoteles melihat politik sebagai kecenderungan alami dan tidak dapat dihindari manusia, misalnya ketika ia mencoba untuk menentukan posisinya dalam masyarakat, ketika ia berusaha meraih kesejahteraan pribadi, dan ketika ia berupaya memengaruhi orang lain agar menerima pandangannya (Pratiwi, 2013). Aristoteles berkesimpulan bahwa usaha memaksimalkan kemampuan individu dan mencapai bentuk kehidupan sosial yang tinggi adalah melalui interaksi politik dengan orang lain. Interaksi itu terjadi di dalam suatu kelembagaan yang dirancang untuk memecahkan konflik sosial dan membentuk tujuan negara.

Dengan demikian kata politik menunjukkan suatu aspek kehidupan, yaitu 
kehidupan politik yang lazim dimaknai sebagai kehidupan yang menyangkut segisegi kekuasaan dengan unsur-unsur: negara, kekuasaan, pengambilan keputusan, kebijakan, dan pembagian atau alokasi (Pratiwi, 2013). Nampaknya tema politik juga menjadi perhatian para pengikut akun Sastraarabcom. Dalam unggahan video tersebut tercatat 20.737 tayang, ini menunjukan bahwa:

"Wahai politisi, wahai budak-budak kursi, mejarah negeri adalah tugasmu yang inti, klaim kebangsaan bagimu adalah satu-satunya kewajibanmu yang asasi, banjiri telinga kami dengan omog kosong dan janji-janji, tampakkan kepahlawananmu yang konyol itu pada kami, manfaatkan saat-saat lemah kami, agar bisa kau perankan cinta dengan segala kebengisannya, seolah-olah kau Grendizer bersekutu dengan Voltron dan Choudenji, bayangkan saja, kau sedang mengosongkan kekuatan pikiran sakitmu itu dari kami, bayangkan saja ia sedang meneriaki kami,bayangkan semua rakyat akan menjerit, berilah kami, tuanku, berilah kami, ayolah... betapa nikmat rasa ini".

Berikut ini contoh tema politik yang dimuat dalam postingan sastraarabcom:

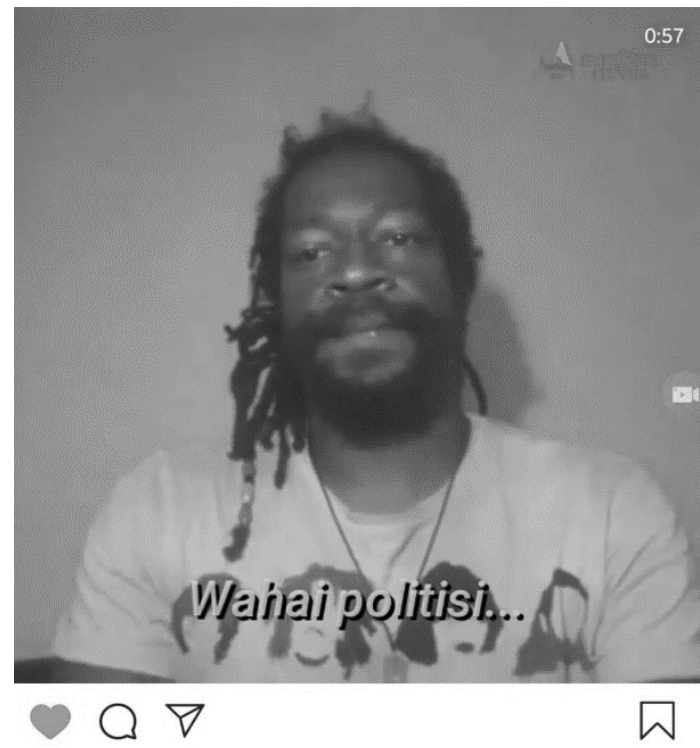

20.737 tayangan • Disukai oleh vivinast__dan farid_lebe

sastraarabcom Kepalkan tangan untuk segala penindasan.. lawan.

lawan.. dan lawan.. | Puisi Penyair Tunis

@anis_chouchene_words_holm.

Teenlit yang ada pada postingan diatas terdapat pada kalimat" wahai budakbudak kursi, banjiri telinga kami dengan omong kosong dan janji-janji (sebagai kalimat konotasi)", dan pada kata "kau, Grendizer, Voltron, Choudenji”.

\section{Gaya bahasa teenlit Sastraarabcom}

Salah satu yang menjadi perhatian bagi kaum remaja adalah gaya bahasa yang digunakan akun Sastraarabcom. Akun ini menampilkan berbagai macam gaya bahasa, diantaranya: Memakai bahasa gaul dan tidak baku 
Pemakaian bahasa gaul dan tidak baku menjadi ciri khas penulis untuk menarik perhatian pembaca, contoh:

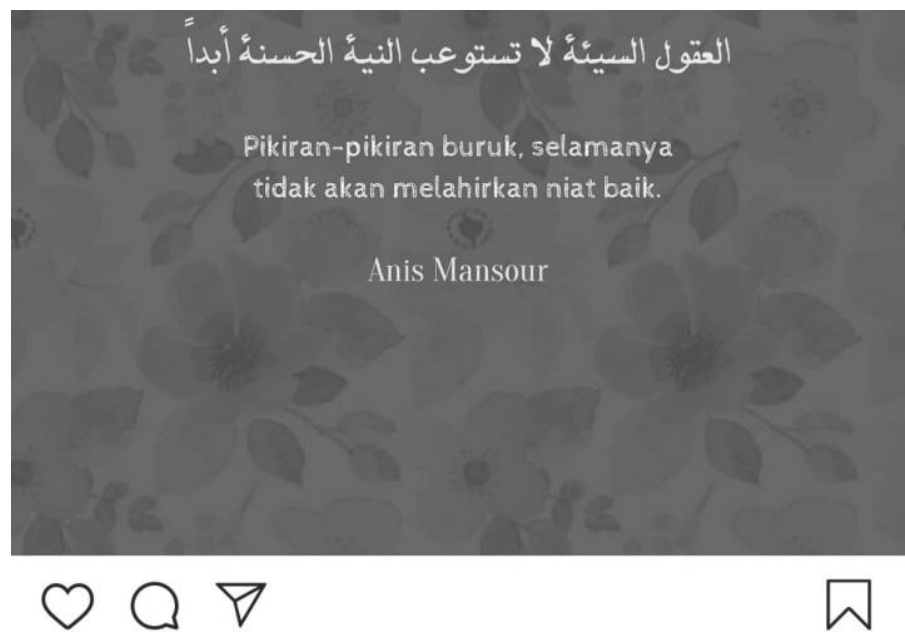

(4) Disukai oleh abdhurobi dan 2.661 lainnya

sastraarabcom Niatku lo udah baik banget sama kamu, tapi kamu abaikan. Karena di matamu yang tampak hanyalah keburukanku.

Pada postingan di atas terdapat caption teenlit dengan kata-kata kekinian“ lo, udah" dalam kalimat" Niatku lo udah baik sama kamu, tapi kamu abaikan. Karena di matamu yang tampak hanyalah keburukan".

\section{Memakai kata Denotasi dan Konotasi}

Pemakaian Denotasi dan Konotasi digunakan penulis untuk memperkuat dan meyakinkan pembaca dalam menyampaikan deskripsinya, contoh:
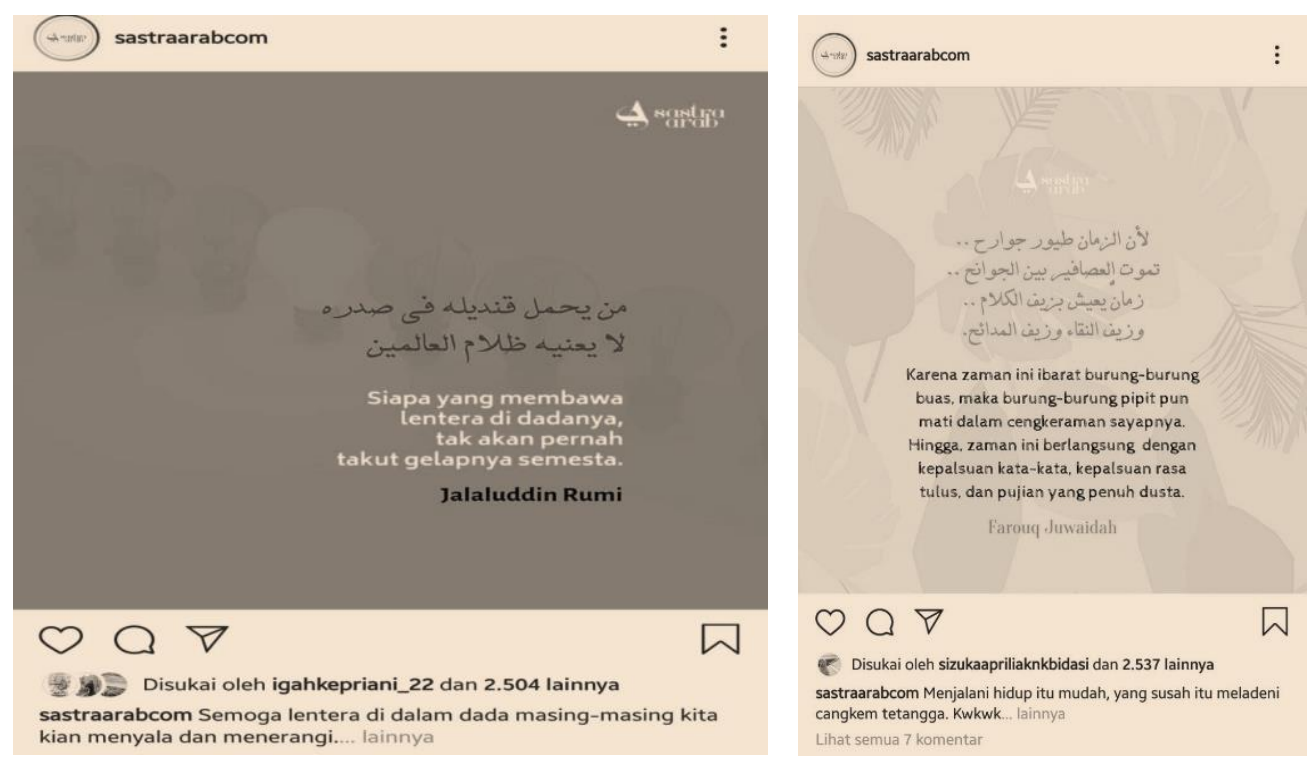

Pada postingan diatas penulis memberi caption "semoga lentera didalam 
dada masing-masing kita kian menyala dan menerangi" (Konotasi). Dan kalimat "burung-burung pitpun mati dalam cengkraman sayapnya" (Denotasi).

\section{Menggunakan kata asing}

Kata asing digunakan penulis untuk menonjolkan kesan gaya kekinian dan terlihat gaul. Contoh:

"menjalani hidup itu mudah, yang susah itu meladeni cangkem tetangga. Kwkwkw."

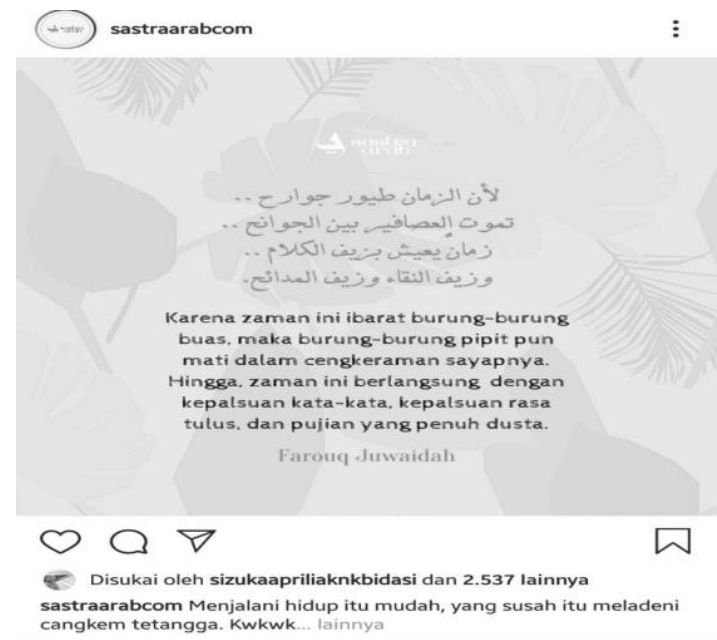
"cangkem".

Pada postingan diatas terdapat caption yang menggunakan kata asing

\section{Eksistensi Teenlit dan Minat Membaca pada Remaja}

Keterampilan yang harus dimiliki siswa salah satunya adalah membaca, melalui membaca, siswa bisa menggali bakat dan potensi mereka, memacu peningkatan daya nalar, melatih konsentrasi, dan peningkatan prestasi sekolah. Melalui kegiatan membaca siswa bisa sekaligus mempelajari mata pelajaran yang lain, dan melalui kegiatan membaca siswa mampu mengetahui segala jenis informasi yang berkembang di sekitarnya dan mengolahnya sebagai ilmu pengetahuan yang dapat diaplikasikannya dalam kehidupan nyata. Mengingat begitu banyak hal yang bisa siswa peroleh dari kegiatan membaca, maka jelas bahwa membaca sangat penting bagi siswa apalagi bila menjadi budaya. Tetapi pada kenyataannya kegiatan membaca masyarakat di Indonesia khususnya para peserta didik masih membutuhkan pembinaan lebih. Minat membaca masyarakat Indonesia masih rendah dan belum dijadikan sebuah kebiasaan.

Minat baca merupakan salah satu kunci sukses seseorang dalam mengetahui dan menambah wawasan pengetahuannya, kegiatan-kegiatan untuk meningkatkan minat baca harus diadakan dan digalakan. Sejalan dengan perkembangan ilmu pengetahuan dan teknologi yang semakin pesat, terutama dalam teknologi percetakan maka semakin banyak informasi yang tersimpan di dalam buku. Pada semua jenjang pendidikan, kemampuan membaca menjadi skala prioritas yang harus dikuasai siswa. dengan membaca siswa akan memperoleh berbagai informasi yang sebelumnya belum pernah didapatkan. Semakin banyak membaca semakin banyak pula informasi yang diperoleh. Oleh karena itu, membaca merupakan 
jendela dunia, siapa pun yang membuka jendela tersebut dapat melihat dan mengetahui segala sesuatu yang terjadi. baik peristiwa yang terjadi pada masa lampau, sekarang, bahkan yang akan dating, banyak manfaat yang diperoleh dari kegiatan membaca. Oleh karena itu, sepantasnyalah siswa harus melakukannya atas dasar kebutuhan, bukan karena suatu paksaan, jika siswa membaca atas dasar kebutuhan, maka ia akan mendapatkan segala informasi yang ia inginkan, namun sebaliknya, jika siswa membaca atas dasar paksaan, maka informasi yang ia peroleh tidak akan maksimal. Membaca merupakan kemampuan yang kompleks, membaca bukanlah kegiatan memandangi lambang - lambang yang tertulis semata.

Bagi siswa, membaca tidak hanya berperan dalam menguasai bidang studi yang dipelajarinya saja, namun membaca juga berperan dalam mengetahui berbagai macam kemajuan ilmu pengetahuan dan teknologi yang ters berkembang. Melalui membaca, kemajuan ilmu pengetahuan dan teknologi dapat diketahui dan dipahami sebalum dapat diaplikasikan. Di Indonesia memang masih saja selalu jadi masalah tanpa pernah diketahui kapan semua ini akan berakhir, namun demikian, berbagai upaya harus terus diperjuangkan untuk meningkatkan budaya baca di masyarakat. Salah satu cara untuk terus mensosialisasikan pentingnya budaya baca, bisa dimulai dari anak-anak hingga remaja dan dewasa, budaya membaca wajib dimulai sedini mungkin di lingkungan keluarga karena akan lebih mudah menanamkan kebiasaan atau sesuatu yang baik dari sejak kecil agar menjadi suatu kebiasaan. Peningkatan kualitas sumber daya manusia terkait dengan minat baca yang membudaya karena usaha tersebut berhubungan langsung dengan proses belajar mengajar. Hambatan yang muncul berkaitan dengan minat baca adalah terbatasnya publikasi buku yang sesuai dengan usia remaja dan dewasa yang menarik, pengaruh lingkungan keluarga dan masyarakat cukup penting, karena keteladanan orang tua memanfaatkan waktu senggang dengan membacakan buku akan meningkatkan motivasi dan kemauan minat baca anak-anaknya, serta analisis dari segi harga buku yang dipasarkan tidak dapat terjangkau.

Lebih dari itu, kehadiran sastra remaja yang lebih populer dengan teenlit cukup memengaruhi minat membaca para remaja. Remaja yang kurang menyukai bacaan berat (sastra serius) memang lebih banyak meminati bacaan teenlit, karena karya jenis ini memang lebih ringan dan mudah dicerna dengan bahasa yang tidak berat dan rumit. Mayoritas remaja mengakui, kegemaran mereka terhadap teenlit disebabkan cerita dan bahasanya yang memang dekat dengan dunia mereka. Fakta bahwa sebagian besar pengarang teenlit sendiri masih remaja, atau paling tidak anak muda menyumbang kepada bercerita yang fasih tentang lika-liku kehidupan remaja sehingga para remaja yang membaca karya mereka merasa dekat dan akrab.

Sastraarabcom adalah media yang memberikan wacana kesusastraan alternatif di Indonesia. Sastraarabcom mencerap, mengolah, dan menyajikan khazanah kesusastraan Arab, sehingga berhasil menarik perhatian nitizen, dengan tema seputar cinta dan pernak-pernik dunia remaja, dan problematika kehidupan remaja, semangat berprestasi, kesetiaan dalam persahabatan. Terlepas dari kritikan tentang aspek mendidik teenlit pada remaja, terbukti dari setiap postingannya berkisar 3.000-28.000 tayang setiap uploadnya (Admin, 2016). Pertumbuhan minat baca di kalangan remaja adalah nyata dan harus disambut dengan baik dan diharapkan semakin menambah wawasan intelektual dan pengalaman hidup remaja. 
Teenlit dalam postingan berikut "ngasih, dedek emesh, dong, lucuk" dalam caption "bantu admin ngasih komentar dedek emesh ini dong...lucuk banget.".

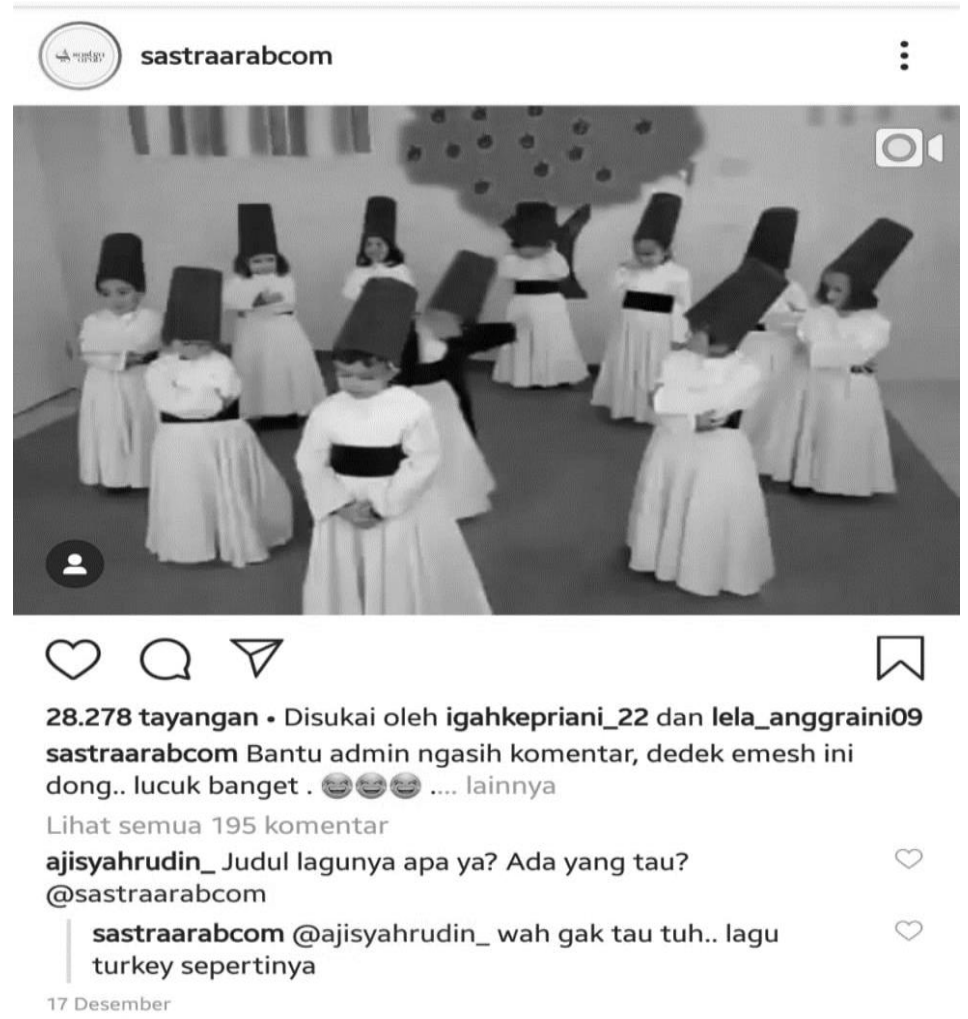

\section{Eksistensi Teenlit dan Minat Menulis pada Remaja}

Menulis merupakan kegiatan yang tidak asing lagi bagi manusia. Bahkan kegiatan menuilis sudah diajarkan oleh orang tua kita semenjak kita kecil. Menulis juga dapat diartikan sebagai menuangkan ide atau gagasan yang ada di pikiran kita. Kegiatan menulis juga diterangkan dalam kitab suci Al-Qur'an yaitu pada QS. Al Qamar: 53 :

(Dan segala (urusan) yang kecil maupun yang besar adalah tertulis) ("Tafsir AlQur'an Online I TafsirWeb," t.t.).

Ayat diatas menerangkan bahwa kegiatan menulis sangat penting kegunaanya, namun sekarang, menulis seakan-akan menjadi kegiatan yang membosankan bagi berbagai kalangan, termasuk bagi kalangan remaja. Kegiatan menulis bagi sebagian remaja merupakan kegiatan yang membosankan, bahkan menulis juga dianggap kegiatan yang membuang waktu. Menulis bagi kalangan remaja hanya dilakukan pada waktu tertentu saja, misalnya pada saat ujian serta hanya untuk menggugurkan kewajiban yakni pada saat remaja diberi tugas oleh dosennya seperti mengerjakan tugas akhir semester dan sebagainya.

Rendahnya minat menulis membaca juga dipengaruhi oleh rendahnya minat membaca seseorang, karena membaca merupakan kegiatan untuk mencari referensi bagi kegiatan menulis, jika kegiatan tersebut tidak dilakukan oleh seseorang atau remaja maka untuk menulis pun tidak akan berhasil, pada umumnya kualitas dan 
kemampuan menulis remaja saat ini cenderung rendah, ini juga membuktikan bahwa, minat membaca remaja sekalipun rendah. Rendahnya minat menulis berdampak pada jumlah publikasi karya imliah yang masih kalah dengan negaranegara lain, adapun jumlah karya ilmiah indonesia bahkan hanya sepertujuh dari negara tetangga yaitu Malaysia. Demikian pula jika dilihat dari jumlah penduduknya pertumbuhan karya tulis indonesia sejak tahun 1996 hingga 2010 masih dibawah negara-negara lain (Nasuha, 2012). Menulis penting bagi remaja, yaitu sebagai sarana untuk menghilangkan stress dan untuk menyegakan pikiran. Selain itu menulis juga berfungsi untuk melatih kekritisan remaja yang tidak ada waktu untuk turun ke jalan terhadap suatu hal yang menjadi suatu permasalahan di masyarakat, kita semua tahu remaja disebut-sebut sebagai "agent of change" atau agen perubahan yang memilki kekritisan terhadap ketidakadilan di masyarakat atau di lingkungan di mana dia berada. Terkadang menulis dapat dijadikan sebagai senjata atau sarana yang paling efektif untuk menciptakan perubahan di masyarakat.

Fenomena teenlit membuka wawasan bahwa aktivitas menulis dapat dilakukan oleh siapa saja, termasuk penulis pemula, bukan semata milik kalangan elit yang berkemampuan lebih. Prosa fiksi teenlit banyak ditulis oleh para remaja putri belia yang juga adalah para penulis pemula. Menurut Wicaksono, menulis merupakan sarana pengembangan daya pikir atau nalar dengan mengumpulkan fakta, menghubungkannya, kemudian menarik simpulannya (Wicaksono, 2014, hlm. 29-30). Dengan menulis dapat memperjelas sesuatu pada diri penulis karena gagasan-gagasan, pikiran-pikiran, apresiasi yang semula masih berserakan dan tidak runtut di dalam pikiran, dapat dituangkan secara runtut dan sistematis (Syahrul, 2018, hlm. 13).

Fenomena teenlit pada postingan akun instagram Sastraarabcom menunjukkan bahwa telah ada pergeseran posisi remaja yang sebelumnya hanya pembaca dan penikmat sastra Arab, kini mereka berkreasi, berinovasi dan berimajinasi mengisahkan dunianya sendiri, karena merekalah yang paling tahu cara berkomunikasi di dalam dunianya. Selain itu, kreativitas remaja dalam menulis juga dapat dilihat dari penggunaan bahasa dalam karya mereka, yaitu bahwa remaja cenderung ingin bebas membentuk konvensi kebahasaan yang mereka ciptakan sendiri. Secara umum, ciri kebahasaan remaja dalam teenlit adalah penggunaan gaya bahasa lisan dalam bahasa tulis, Bahasa gaul dan bahasa tren dalam dunia remaja pun masuk dalam karya mereka.

Banyak para nitizen yang tertarik untuk menulis pada sastraarabcom, tulisan yang mereka kirim kemudian ditampilkan dalam blog sastraarabcom. Hampir stiap minggu sastraarab.com menampilkan tulisan-tulisan yang dikirim oleh para followernya. Berbagai macam gaya bahasa yang ditulis mulai dari yang baku, tidak baku, gaul yang dihadirkan dalam gaya bertutur buku harian adalah aspek yang menonjol pada sastraarabcom. Gaya bahasa demikian lebih membangkitkan keterlibatan para pembacanya, dan mencerminkan budaya remaja, yang sedang dalam masa kritis pencarian jati diri, pada blog sastraarabcom mengkaji semua elemen yang ada dalam kehidupan. Didalamnya mencakup tentang politik, hukum, budaya, hiburan, lingkungan, wisata, kesehatan dan sebagainya. Dengan penuh gaya bahasa yang bervariasi, blog sastraarabcom akan menyapa pembaca dengan sentuhan jurnalisme khas untuk selalu memberikan lebih dari sekadar pengetahuan, 
apalagi ditunjang dengan kreatifitas visual yang progresif dan tidak konservatif. Blog sastraarabcom selalu menyapa pembacanya karena pemanfaatan bahasa dan image yang ramah (tidak berdarah-darah), aktual dan informatif, membuat pembacanya memahami betul apa maksud dari tulisan yang ada didalamnya, apalagi informasi yang disajikan ringkas dengan topik-topik yang hangat, tidak membuat kening berkerut pastinya. Tulisan-tulisan didalamnya bersifat Young and Friendly Magazine, tercemin dari penggunaan bahasa yang renyah dan sarat dengan unsur partisipasi publik, dan dan mampu menyajikan gaya hidup yang meliputi in depthnews, lifestyle, sport, dan entertainment. Jadi sangat jelas tulisan-tulisan pada blog sastraarabcom ini sangat menarik untuk di hadirkan dalam kehidupan kita, selain mendidik juga menumbuhkan minat belajar yang baik.

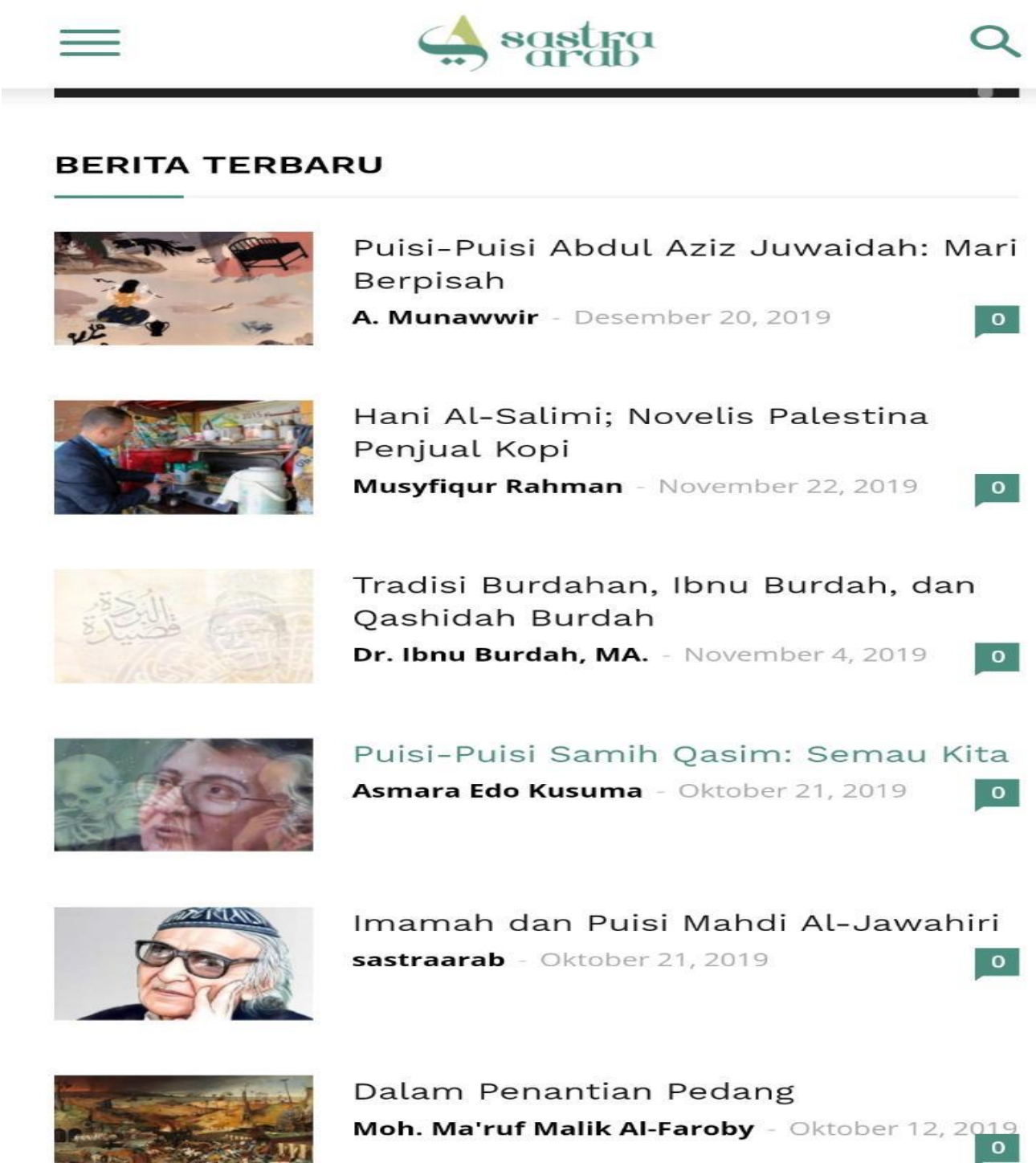

\section{PENUTUP}

Dari hasil pembahasan di atas, dapat disimpulkan bahwa membaca teenlit 
dengan ancangan literasi kritis dapat menjadi media alternatif dalam meningkatkan literasi remaja untuk mampu membaca dan memahami isi bacaan. Macam-macam teenlit pada postingan akun instagram sastraarabcom dapat dijadikan sebagai salah satu media dan materi alternatif dalam meningkatkan literasi remaja dalam pembelajaran apresiasi sastra karena sastraarabcom sesuai dengan minat dan perkembangan pembaca dan mengandung berbagai macam nilai positif yang berguna bagi kehidupan. Penggunaan teks sastra secara langsung dalam proses pembelajaran apresiasi sastra dapat mencetak remmaja yang tidak hanya pandai dalam hal berteori sastra saja, tetapi juga dapat mencetak remaja yang berbudi, toleran, dan berbudaya.

\section{DAFTAR PUSTAKA}

Admin. (2016). Sastraarabcom.

Anggraini, N. (2014). Puitika Pada Novel-Novel Teenlit. Universitas Bengkulu.

Arman, D. (2011). Kata Kata Bijak tentang Kehidupan. Kata Kata Bijak Albert Einstein. http://armandjexo.blogspot.com/2011/10/kata-kata-bijak-tentang-kehidupan.html

Bijak, L. (2019). Lenteraku [Blog]. Pengertian Kata Mutiara. https://www.lenterabijak.com/pengertian-kata-mutiara

Dewojati, C., \& Sugihastuti. (2010). Wacana hedonisme dalam sastra populer Indonesia (Cet. 1). Pustaka Pelajar.

Efendi, F., \& Nursalam. (2008). Pendidikan Dalam Keperawatan. Salemba Medika.

Kusmarwanti. (2005). "Teenlit" dan Budaya Menulis di Kalangan Remaja, "Menuju Budaya Menulis: Sebuah Bunga Rampai",. Tiara Wacana.

Mahmud. (1987). Sastra Indonesia dan Daerah: Sejumlah Masalah. Angkasa.

Mönks, F. J., Knoers, A. M. P., \& Haditono, S. R. (1984). Psikologi perkembangan: Pengantar dalam ber bagai bagiannya. Gadjah Mada University Press.

Nasuha, M. A. (2012). Rendahnya Minat Menulis Di Kalangan. Universitas Sebelas Maret Surakarta.

Pramesthi, A. R. (2011). Pemanfaatan Teenlit Sebagai Alternatifbahan Pembelajaran Apresiasi Sastrauntuk Siswa Sma. Universitas Negeri Semarang.

Pratiwi, R. (2013). Politik dan Strategi Nasional (Pengertian Politik dan Strategi Nasional, Dasar Pemikiran Dan Penyusunan Politik dan Strategi Nasional)

Sumardjo, J., \& Saini, K. M. (Ed.). (1995). Antologi Apresiasi Kesusastraan (Cet. 1). Gramedia Pustaka Utama.

Suroto. (1989). Teori dan bimbingan apresiasi sastra Indonesia. Erlangga.

Syahrul, N. (2018). "Sastra Remaja (Teenlit) sebagai Media Alternatif dalam meningkatkan Budaya Literasi". PARAFRASE: Jurnal Kajian Kebahasaan \& Kesastraan, 17(2). 
https://doi.org/10.30996/parafrase.v17i2.1367

Tafsir Al-Qur'an Online | TafsirWeb. (t.t.). TafsirWeb. https://tafsirweb.com/about

Tri Priyatni, E. (2010). Membaca sastra dengan ancangan literasi kritis (Cet. 1). Bumi Aksara.

Wellek, R., Warren, A., \& Budianta, M. (2014). Teori kesusastraan.

Wicaksono, A. (2014). Menulis Kreatif Sastra dan Beberapa Model Pembelajarannya. Garudhawaca.

\section{LAMPIRAN}
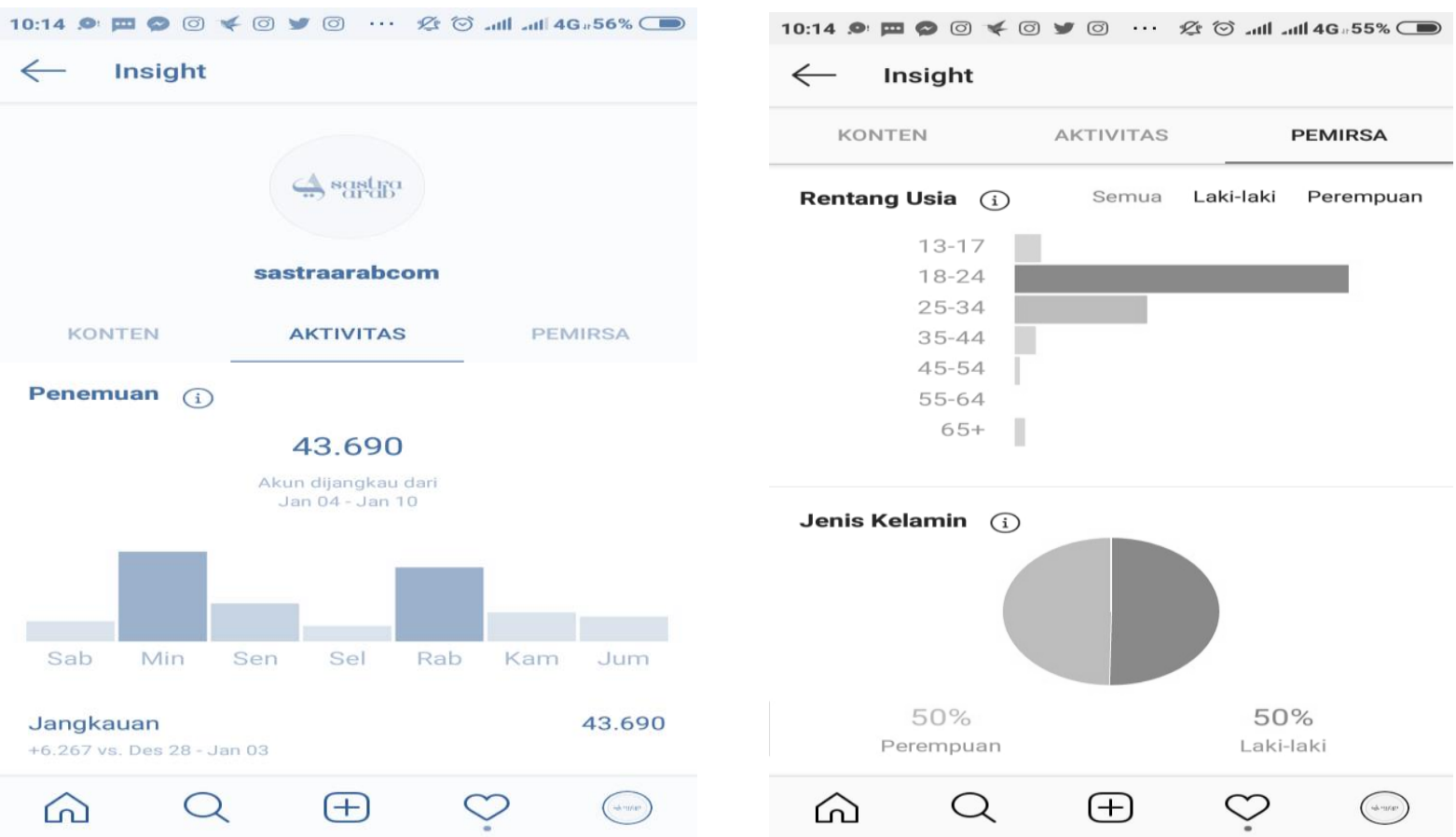